DOI:10.22337/2587-9618-2020-16-2-94-100

\title{
ANALYSIS OF RHEOLOGICAL MODELS OF PROCESS OF SELF-FORMING OF GLUED WOODEN
}

\author{
Vladislav S. Ponomarev, Galina G. Kashevarova \\ ${ }^{1}$ Perm National Research Polytechnic Universities, Perm, RUSSIA
}

\begin{abstract}
The article considers a promising technology for self-shaping glued wooden elements of curved forms. This method is based on rheological processes occurring in wood, such as dehumidification and swelling of wood and its anisotropic properties. To predict the final curved shape of the wooden structure, the authors analyzed existing rheological models of wood and concluded that the rheological model proposed by European researchers includes the most complete list of factors that affect the process of deformation of wood: elastic and plastic deformation, drying and swelling of wood, deformation of viscous-elastic creep and mechanical sorption deformation. Based on the results of experimental studies and numerical modeling of the change in the curvature of glued wooden elements, which were made by European researchers, it was found that the proposed rheological model of wood needs to be clarified, namely, the correction of hygro-expansion coefficients depending on the moisture content of wood. A further direction of the authors' research will be aimed at conducting model experiments to determine the hygro-expansion coefficients of different grades of wood depending on the thickness of the wooden elements and the orientation of the layers in the glued structure.
\end{abstract}

Keywords: method of self-shaping of glued wooden structures, rheological model, deformation.

\section{АНАЛИЗ РЕОЛОГИЧЕСКИХ МОДЕЛЕЙ ПРОЦЕССА САМО-ФОРМООБРАЗОВАНИЯ КЛЕЁНЫХ ДЕРЕВЯННЫХ КОНСТРУКЦИЙ}

\author{
В.С. Пономарев, Г.Г. Кашеварова
}

Пермский национальный исследовательский политехнический университет, г. Пермь, РОССИЯ

\begin{abstract}
Аннотация: В статье рассмотрена перспективная технология само-формообразования клеёных деревянных элементов конструкций изогнутой формы. Данный метод основан на реологических процессах, происходящих в древесине, таких как деформации усушки и набухания древесины и ее анизотропных свойствах. Для прогнозирования конечной изогнутой формы деревянной конструкции, авторы проанализировали существующие реологические модели древесины и пришли к выводу о том, что в настоящее время реологическая модель, предложенная Европейскими исследователями, включает в себя наиболее полный перечень факторов, которые влияют на процесс деформации древесины: упругая и пластическая деформация, усушка и набухание древесины, деформация вязко-упругой ползучести и механо-сорбционная деформация. На основании результатов экспериментальных исследований и численного моделирования изменения кривизны клеёных деревянных элементов, которые были выполнены Европейскими исследователями, было установлено, что предложенная реологическая модель древесины нуждается в уточнении, а именно в корректировке коэффициентов гидрорасширения в зависимости от влажности древесины. Дальнейшее направление исследования авторов будет направлено на проведение натурных экспериментов по определению коэффициентов гидрорасширения различных сортов древесины в зависимости от толщины деревянных элементов и ориентации слоев в клееной конструкции.
\end{abstract}

Ключевые слова: метод само-формообразования клеёных деревянных конструкций, реологическая модель, деформация 


\section{INTRODUCTION}

In modern construction practice, the use of wooden structures is widespread. Over the past ten years, unique wood facilities have been built in Western Europe, such as "Las Setas de Sevilla", also known as the "Metropol Parasol" in Seville (Figure 1), the viewing tower on Pyramidenkogel in Austria (Figure 2), apartment building in London "The Cube" etc.

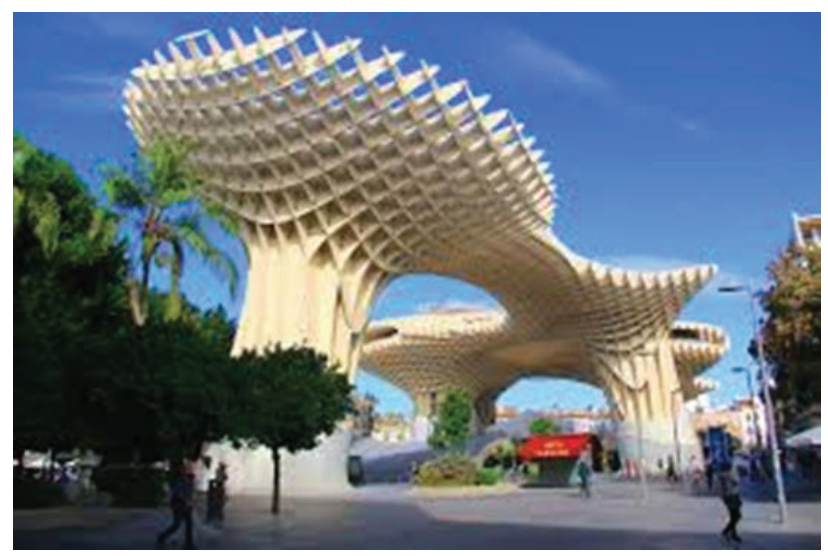

Figure 1. Las Setas de Sevilla.

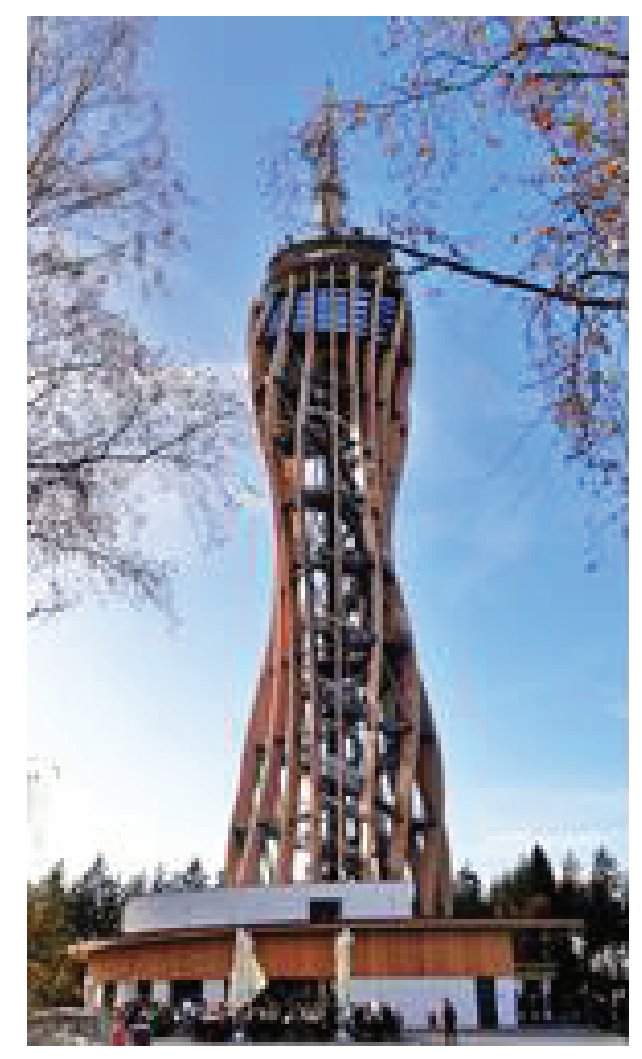

Figure 2. The viewing tower on Pyramidenkogel.
The world practice of using wooden structures pushes scientists to study the natural structure of wood for its effective use as a building material. The variety of wood products requires the development of methods for calculating structures from this material. A great deal of knowledge and experience in wood design is now being developed, but there are a number of issues that remain unresolved [1-4].

Wood - natural anisotropic material. A distinctive feature of its structure is the specific orientation of various tissues in it. Their directional arrangement forms a fibrous structure. In addition, and concentrically arranged annual rings give the wood a layered structure [5].

The unique structure of wood gives the wood exceptional advantages: relatively low density, high specific tensile strength along the fibers, resistance to salt aggression and other chemically active substances, high aesthetic and acoustic properties, etc. At the same time, wood defects, such as knot cluster, spiral grain, porosity, bultswell, reduce the quality of products and structures. Low fire resistance, decay and damages by bugs require additional protection measures for wooden structures. Anisotropy and change in physical and mechanical properties significantly limit the field of application of wood. But at the beginning of the second decade, based on the scientific works of S.P. Tymoshenko [6], several researchers from Switzerland and Germany [7] proposed a technology for using these shortcomings of wood to produce glued wooden structures of complex architectural shape. They called their method "self-shaping glued wooden structures".

\section{METHOD OF SELF-SHAPING OF GLUED WOODEN STRUCTURES}

Self-shaping method used for the production of glued wooden structures of curved shape. This method is based on the processes of drying and swelling of wood, as well as on its anisotropy. To give a curved shape, two layers are distinguished 
in a glued wooden structure: active and passive (Figure 3).

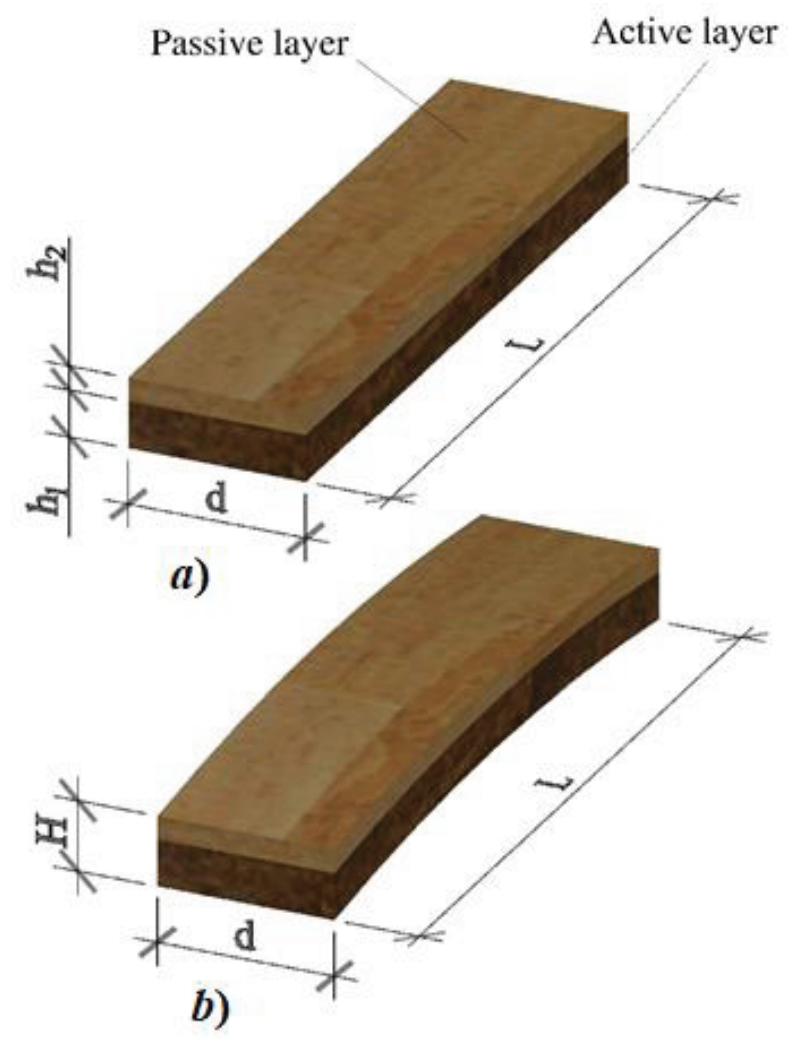

Figure. 3. (a) - wood element before drying; (b) - wood element after drying:

$L$ - length, $d$-width, $H$ - general thickness, $h_{1}$ - thickness of the active layer, $h_{2}$ - thickness of a passive layer.

The main idea of the self-shaping method is that when the active layer is moistened to a certain value before gluing the layers of wood, the layer swells and increases in size. After that, the active and passive layers are glued together.

During drying of the glued wooden structure, moisture from the wood of the active layer is removed, and it decreases in size. The passive layer resists deformation of the active layer, as a result of which the glued wooden structure acquires a curved shape. The curvature of the structure depends on several factors, such as mechanical properties of the wood (modulus of elasticity, modulus of shear, Poisson's coefficient), humidity and thickness of the active and passive layers, orientation of the layers.

\section{DESCRIPTION OF RHEOLOGICAL WOOD MODELS}

The application of the self-shaping method of glued wooden structures requires the most complete and accurate rheological model of wood to predict the final shape of the structures. To date, scientists from around the world are conducting research to refine or develop a new rheological model of wood.

For example, E. M. Tyuleneva [8] proposed her rheological model of wood, in which the complete relative deformation of wood is defined as

$$
\varepsilon=\frac{\sigma}{E_{1}}+\frac{\sigma}{E_{2}}+\frac{\sigma}{E_{3}}\left(1-e^{-\frac{E_{2}}{\eta_{2}} t}\right)
$$

where $\sigma$-stress in wood, $E_{1}$ - instant module of elasticity, $E_{2}$ - elastic modulus of the second kind, $E_{3}$ - plastic module of deformation, $\eta_{2}$ elasticity coefficient, $t$ - loading time of wooden specimen.

A group of researchers Vasilenko A. S. and Yudin R. V. conducted studies to determine the deformation of wood in the manufacture of sleepers. The authors of article [9] proposed a mathematical model in which the total relative deformation of wood is defined as

$$
\varepsilon=\frac{\sigma}{E_{M}}+\frac{\sigma}{E_{M}}\left(\frac{E_{M}}{E_{g}}-1\right)\left(1-e^{-\left(\frac{E_{g}}{E_{M}}\right)\left(\frac{t}{n}\right) \alpha}\right)
$$

where $\sigma$-stress in wooden element, $E_{M}$ - instant elastic modulus, $E_{g}$ - long modulus of elasticity, which characterizes the final elastically elastic state of wood, $t$ - loading time, $n$ - relaxation time, $\alpha \leq 1$ - rheological coefficient.

Foreign researchers Hassani M. M. and others from Germany and Switzerland, who proposed the method of self-shaping, developed their own rheological model of wood [10]. It defines the total relative deformation of wood as the sum of five components (Figure 4): 


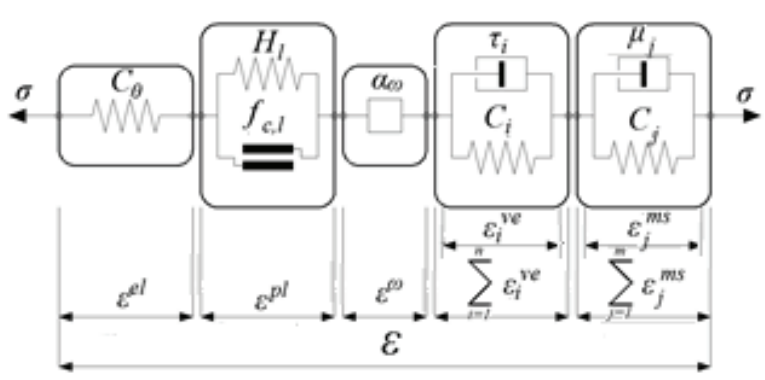

Figure. 4. Schematic illustration of the rheological model of wood [7].

- elastic deformation $\varepsilon^{e l}$;

- irrecoverable plastic deformation $\varepsilon^{p l}$;

- deformation of drying or swelling caused by change in moisture content of wood $\varepsilon^{\omega}$;

- deformation of viscous-elastic creep $\varepsilon_{i}^{v e}$;

- deformation of mechano-sorption creep $\varepsilon_{j}^{m s}$.

As a result, the tensor of complete relative deformation of wood consists of five components:

$$
\varepsilon=\varepsilon^{e l}+\varepsilon^{p l}+\varepsilon^{\omega}+\sum_{i=1}^{n} \varepsilon_{i}^{v e}+\sum_{j=1}^{m} \varepsilon_{j}^{m s}
$$

The key feature of this model is the determination of the deformation of drying and swelling of wood, since it is it that plays an important role in the method of self-shaping of glued wooden structures. When drying wood, moisture inside the wood moves to the surface, and moisture evaporates from the surface of the material into the environment. With a decrease or increase in moisture, wood shrinks or swells.

To describe deformation in these processes, the authors [10] proposed to use an approach similar to the thermal expansion of the material. Change of linear dimensions of wood in different anatomical directions directly proportional to increase of wood humidity [10]:

$$
\varepsilon^{\omega}=\alpha_{\omega}\left(\operatorname{Min}\left(\omega, \omega_{F S}\right)-\omega_{0}\right)
$$

where $\omega$ - current humidity of material, $\omega_{F S}$ moisture content of wooden specimen, at the value of which shrinkage or swelling does not occur (for a number of sources this value varies from 28 to 30 percent [11]), $\omega_{0}$ - final humidity of wood. The vector $\alpha_{\omega}$ consists of hydraulic expansion coefficients and in the coordinate system $R T L(R, T, L$ - the anatomical direction of wood growth: radial, tangential longitudinal) is defined as

$$
\alpha_{\omega}=\left\{\alpha_{R}, \alpha_{T}, \alpha_{L} ; 0,0,0\right\}
$$

The authors [10] assume that the coefficients are $\alpha_{R}, \alpha_{T}, \alpha_{L}$ constant for each type of wood and do not depend on the level of humidity. Coefficient values are given in [10]

Analyzing the presented rheological models of wood behavior, we can say that the rheological model proposed by foreign authors takes into account more factors affecting wood deformation. For the practical application of the self-forming method of glued laminated wooden structures, accounting for the deformation of drying and swelling of wood is the most important factor for predicting the final curved shape of the wooden structure.

\section{VERIFICATION OF THE RHEOLOGICAL MODEL OF WOOD}

Based on the above-described rheological model of wood (4) and the method of self-shaping of glued wooden structures, a numerical simulation of the deformation process of wooden beams was carried out in order to verify the rheological model with natural experimental studies (Figure 5) [7].

As the material of the initial samples, two varieties of wood were used European beech and Norwegian spruce. A total of three types of specimens $600 \mathrm{~mm}$ length, $100 \mathrm{~mm}$ wide and 15, 30 and $45 \mathrm{~mm}$ thick, specimen number 1,2 and 3 respectively, were tested. The ratio of the thickness of the active layer of the passive layer was $1: 2$.

The passive layer was made of a solid board 600 $\mathrm{mm}$ long and $100 \mathrm{~mm}$ wide, and the active layer was made of a board $250 \mathrm{~mm}$ long and $100 \mathrm{~mm}$ wide. 


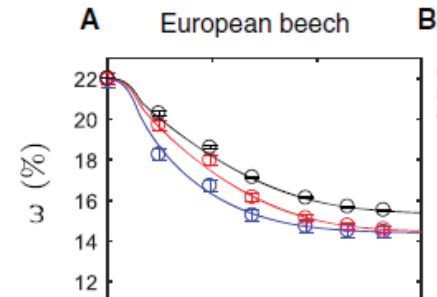

B Norway spruce
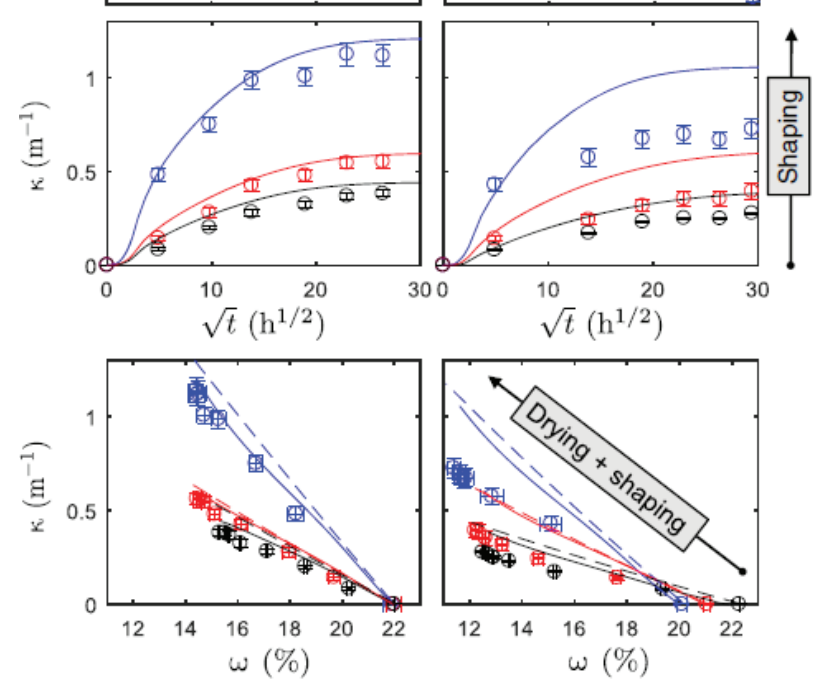

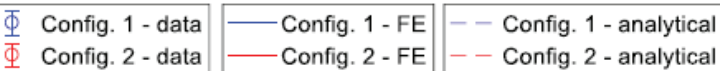

$\Phi$ Config. 3 - data - Config. 3 - FE -- Config. 3 - analytical

\section{Figure. 5. Results of reshaping samples after} drying. Bilayer samples (configurations 1-3) made of European beech (A) and Norwegian spruce (B). Moisture change of wood $(\omega)$ modeled by finite element method and measured on experimental samples. Curvatures ( $k$ ) versus square root of time, and curvatures versus moisture contents with comparison to model predictions [7].

A polymer adhesive composition was used to glue the active and passive layers. In addition, the researchers conducted an analytical and numerical calculation of the deformation of glued wooden structures made by method of self-shaping.

Analyzing the obtained values of deformations of glued wooden beams, obtained from the results of full-scale experiments, numerical modeling and analytical calculation, we can conclude that: - in the process of drying both wood grades, the humidity and time changes obtained during the full-scale experiment and as a result of numerical modeling are close to each other;

- for European beech, the dependencies of the change in curvature (shape change) of the sample on the time and moisture of wood, obtained during the full-scale experiment and as a result of numerical modeling, are also close to each other, but for Norwegian spruce, similar dependencies differ: the beam curvature according to the results of numerical modeling is greater than the curvature obtained during the full-scale experiment.

\section{CONCLUSION}

The method of self-shaping of glued wooden structures is a promising technology for designing and producing building structures of unique architectural forms from wood. This method is based on rheological processes occurring in anisotropic material, drying and swelling of wood. Studying the change in the mechanical characteristics of various types of wood due to an increase or decrease in its humidity will allow you to more accurately predict the final form of wooden structures made by self-forming.

Currently, the rheological model (4), describing the complete relative deformation of wood as the sum of five components: elastic and plastic deformation, drying or swelling of wood, deformation of viscous-elastic creep and mechanicalsorption deformation, needs to be clarified. This was shown by the results of field experiments and numerical modeling. According to the authors, these discrepancies can be caused by not taking into account the influence of thickness and orientation of the active layers in determining the factors of hygro-expansion coefficients of wood (6) $[10]$.

Further research on the mechanical behavior of wood by the authors will focus on refining the mathematical model of the processes of drying and swelling of wood and conducting full-scale experiments to determine the hygro-expansion coefficients at different thicknesses and arrangement of wooden elements. 


\section{REFERENCES}

1. Kalugin A.V. Dereviannye konstruktsii: ucheb. posobie [Wooden construction: educational book]. Moscow, ASV Publishing House, 2008, 288 pages (in Russian).

2. Sobolev Iu.S. Drevesina kak konstruktsionnyi material [Wood as a construction material]. Moscow, Lesnaia promishlennost, 1979, 248 pages (in Russian).

3. Piatikrestovskii K.P. Nelineinye metody mekhaniki v proektirovanii sovremennykh dereviannykh konstruktsii [Nonlinear methods of mechanics in the design of modern wooden structures]. Moscow, MISI-MGSU Publishing House, 2017, 320 pages (in Russian).

4. Filimonov Je.L at el. Konstrukcii iz dereva i plastmass [Structures made of wood and plastics: Tutorial]. Moscow, ASV Publishing House, 2010, 440 pages (in Russian).

5. Chudinov B.S. Voda $\mathrm{v}$ drevesine [The water in the wood]. Novosibirsk, Nauka, 1984, 270 pages (in Russian).

6. Timoshenko S.P., Lessel's Dzh. Prikladnaja teorija uprugosti [Applied theory of elasticity]. Leningrad, Gosudarstvennoe tehnicheskoe izdatel'stvo, 1931, 394 pages (in Russian).

7. Grönquist P., Wood D., Hassani M.M., Wittel F.K., Menges A., Rüggeberg $M$. Analysis of hygroscopic self-shaping wood at large scale for curved mass timber structures. // Science Advances, 2019, Volume 5, Number 9.

8. Tiuleva E.M. Utochnenie reologicheskoi modeli drevesiny [Clarification of the rheological wood model]. // Khvoinye boreal'noi zony, 2008, Volume 1-2, pp. 179183 (in Russian).

9. Iudin R.V., Vasilenko A.S. Matematicheskaia model' reologicheskikh iavlenii deformirovaniia drevesiny dlia izgotovleniia shpal [Mathematical model of rheological phenomena of wood deformation for the production of sleepers]. // Aktual'nye napravleniia nauchnykh issledovanii XXI veka: teoriia i praktika (Current directions of scientific research of the XXI century: theory and practice).Voronezh, 2017, pp. 301-306.

10. Hassani M.M., Wittel F.K., Hering S., Herrmann H.J. Rheological model for wood. // Comput. Methods Appl. Mech. Engrg, 2014, Volume 283, pp. 1032-1060.

11. Peich N.N., Tsarev B.S. Sushka drevesiny [Wood drying]. Moscow, Vysshaia shkola, 1971, 220 pages (in Russian).

\section{СПИСОК ЛИТЕРАТУРЫ}

1. Калугин А.В. Деревянные конструкции. - М.: ACB, 2008. - 288 с.

2. Соболев Ю.С. Древесина как конструкционный материал. - М.: Лесная промышленность 1979. - 248 с.

3. Пятикрестовский К.П. Нелинейные методы механики в проектировании современных деревянных конструкций. М.: Изд-во МИСИ-МГСУ, 2017. - 320 с.

4. Филимонов Э.В. и др. Конструкции из дерева и пластмасс. - М.: АСВ, 2010. $440 \mathrm{c}$.

5. Чудинов Б. С. Вода в древесине. - Новосибирск: Наука, 1984. - 270 с.

6. Тимошенко С.П., Лессельс Дж. Прикладная теория упругости. - Л.: Государственное техническое издательство, 1931. - 394 c.

7. Grönquist P., Wood D., Hassani M.M., Wittel F.K., Menges A., Rüggeberg M. Analysis of hygroscopic self-shaping wood at large scale for curved mass timber structures. // Science Advances, 2019, Volume 5, Number 9.

8. Тюлева Е.М. Уточнение реологической модели древесины. // Хвойные бореальной зоны, 2008, №1-2, с. 179-183.

9. Юдин Р.В., Василенко А.С. Математическая модель реологических явлений 
деформирования древесины для изготовления шпал. // Актуальные направления научных исследований XXI века: теория и практика. Воронеж, 2017, с. 301-306.

10. Hassani M.M., Wittel F.K., Hering S., Herrmann H.J. Rheological model for wood. // Comput. Methods Appl. Mech. Engrg, 2014, Volume 283, pp. 1032-1060.

11. Пейч Н.Н., Царев Б.С. Сушка древесины. - М.: Высшая школа, 1971. - 220 c.

Vladislav S. Ponomarev, post-graduate student of department "Building constructions and computational mechanics", Perm National Research Polytechnic University; 109, ul. Kuibyshev, Perm, 614010, Russia;

Phone +7 (342) 219-83-61;

Ee-mail: vlad59russia@mail.ru.

Galina G. Kashevarova, Corresponding Member of Russian Academy of Architecture and Construction Sciences, Professor, Dr.Sc., Head of department "Building constructions and computational mechanics", Perm National Research Polytechnic University; 109, ul. Kuibyshev, Perm, 614010, Russia; phone +7 (342) 219-83-61;

E-mail: ggkash@mail.ru.

Пономарев Владислав Семенович, аспирант кафедры «Строительные конструкции и вычислительная механика» Пермского национального исследовательского политехнического университета; 614010, Россия, г. Пермь, ул. Куйбышева, 109; тел. +7(342) 219-83-61; e-mail: vlad59russia@mail.ru.

Кашеварова Галина Геннадьевна, член-корреспондент Российской академии архитектуры и строительных наук (РААСН), доктор технических наук, профессор, заведующая кафедрой «Строительные конструкции и вычислительная механика» Пермского национального исследовательского политехнического университета; Россия 614010, г. Пермь, ул. Куйбышева, 109;

тел. +7(342) 219-83-61;

E-mail: ggkash@mail.ru. 